\title{
Association of single nucleotide polymorphisms in CYP1B1 and COMT genes with breast cancer susceptibility in Indian
}

\section{women}

\author{
Sharawan Yadav ${ }^{\mathrm{a}, 1}$, Naveen Kumar Singhal ${ }^{\mathrm{a}, 1}$, Virendra Singh ${ }^{\mathrm{a}}$, Neeraj Rastogi ${ }^{\mathrm{b}}$, \\ Pramod Kumar Srivastava ${ }^{\mathrm{c}}$ and Mahendra Pratap Singh ${ }^{\mathrm{a}, *}$ \\ ${ }^{a}$ Indian Institute of Toxicology Research (Council of Scientific and Industrial Research), Lucknow- 226 001, India \\ ${ }^{\mathrm{b}}$ Sanjay Gandhi Post Graduate Institute of Medical Sciences, Lucknow- 226 014, India \\ ${ }^{\mathrm{c}}$ Banaras Hindu University, Varanasi-221 005, India
}

\begin{abstract}
Cytochrome P450 1B1 (CYP1B1) and catechol-O-methyltransferase (COMT) enzymes play critical roles in estrogen metabolism. Alterations in the catalytic activity of CYP1B1 and COMT enzymes have been found associated with altered breast cancer risk in postmenopausal women in many populations. The substitution of leucine (Leu) to valine (Val) at codon 432 increases the catalytic activity of CYP1B1, however, substitution of Val to methionine (Met) at codon 158 decreases the catalytic activity of COMT. The present study was performed to evaluate the associations of CYP1B1 Leu ${ }^{432} \mathrm{Val}$ and/or COMT $\mathrm{Val}^{158}$ Met polymorphisms with total, premenopausal and postmenopausal breast cancer risks in Indian women. COMT and CYP1B1 polymorphisms in controls and breast cancer patients were analyzed employing polymerase chain reaction-restriction fragment length polymorphism (PCR-RFLP) followed by gel electrophoresis. Although CYP1B1 and COMT genotypes did not exhibit statistically significant association with breast cancer risks when analyzed individually, COMT wild type (Val $\left.{ }^{158} \mathrm{Val}\right)$ in combination with CYP1B1 heterozygous variant $\left(\mathrm{Leu}^{432} \mathrm{Val}\right.$ ) [OR: $0.21 ; 95 \% \mathrm{CI}(0.05-0.82)$, p value; 0.021] and COMT heterozygous variant $\left(\mathrm{Val}^{158} \mathrm{Met}\right)$ in combination with CYP1B1 wild type (Leu $\left.{ }^{432} \mathrm{Leu}\right)$ [OR: 0.29; 95\% CI (0.08-0.96), p value; 0.042] showed significant protective association with premenopausal breast cancer risk. The results demonstrate that CYP1B1 wild type in combination with COMT heterozygous or their inverse combination offer protection against breast cancer in premenopausal Indian women.
\end{abstract}

Keywords: Breast cancer, genetic polymorphism, CYP1B1, COMT

\section{Introduction}

Circulating level of estrogens regulates the incidences of breast cancer in postmenopausal women [1, 2]. Xenobiotic metabolizing genes involved in estro-

\footnotetext{
${ }^{1}$ Equal contribution, IITR Communication Number: 2757.

*Corresponding author: Mahendra Pratap Singh, Indian Institute of Toxicology Research, Mahatma Gandhi Marg, Post Box- 80, Lucknow- 226 001, UP, India. Tel.: +91 522 2620106/2614869 Ext. 337; Fax: +91 522 2628227; E-mail: singhmahendrapratap@ rediffmail.com.
}

gen metabolism act as important contributors in the regulation of circulating level of estrogens [3]. Single nucleotide polymorphism in cytochrome P450 1B1 (CYP1B1) and catechol- $O$-methyltransferase (COMT) have been associated with increased incidences of breast cancer risk in many populations, however, lack of such associations have been also reported [4-8]. CYP1B1 and COMT play an important role in estrogen metabolism. CYP1B1 gene, located on short arm of chromosome 2, consists of three exons and four introns, spans 8546 base pairs and encodes a protein of 
543 amino acids $[9,10]$. COMT gene is localized on long arm of chromosome 22 and contains two separate promoters on the same chromosome for its two isoforms $[11,12]$. COMT gene encodes either a soluble protein containing 221 amino acid residues or a membrane bound protein containing 271 amino acids along with 50 additional residues at its $\mathrm{N}$-terminal end [13, 14].

CYP1B1 enzyme catalyzes 4-hydroxylation of estrogens and COMT converts catechol derivatives of estrogens mostly into inactive metabolites $[15,16]$. Hydroxylated intermediates are generally metabolized into water-soluble methyl derivatives and easily excreted from human body [17]. Hydroxylated products produce estrogenic and carcinogenic effects, if not metabolized, however, 4-hydroxyestradiol exhibits more pronounced effects than 2-hydroxyestradiol [18,19]. Leucine (Leu) to valine (Val) substitution at codon $432(\mathrm{C} / \mathrm{G})$ in exon 3 of CYP1B1 gene exhibits three times higher activity than wild type in vitro, however, Leu substitution is associated with altered protein activity in presence of other CYP1B1 polymorphisms [20,21]. Substitution of Val to methionine (Met) (Val108/158Met) at position $158(\mathrm{G} / \mathrm{A})$ in exon 4 of membrane bound COMT causes the protein to become 2-3-fold less active in vitro, as compared with its wild type protein [22].

Postmenopausal breast cancer is associated with obesity and estrogen levels that are directly or indirectly influenced by life style, environmental exposure and food habits [3]. Despite variability in life style, multiple ethnicity, environmental exposure and food habits [2325], the association studies on estrogen metabolism with breast cancer risk in north Indian women have been rarely studies. Associations of polymorphisms in some of the estrogen metabolizing genes with breast cancer risk were evaluated recently in Indian population [25]. Despite established association of polymorphisms of estrogen metabolizing genes, such as CYP1A1 with postmenopausal breast cancer risk in several populations, lack of significant associations with postmenopausal breast cancer risk were observed in Indian women, although heterozygocity of CYP1A1 M2 polymorphism was found protective against postmenopausal breast cancer [25]. Variability in association studies of one of the estrogen metabolizing genes with breast cancer risk in Indian women has prompted us to look into the contribution of genetic polymorphisms of other estrogen metabolizing genes, such as CYP1B1 and COMT in breast cancer risks. The exploratory character of the study was to assess whether premenopausal or postmenopausal breast cancer risks in Indian women are associated with the CYP1B1 and COMT polymorphisms or not.

\section{Material and methods}

\subsection{Selection of subjects, blood collection and genotyping}

The blood was collected from female controls and breast cancer patients by clinicians at Sanjay Gandhi Postgraduate Institute of Medical Sciences (SGPGIMS), Lucknow, on the basis of inclusion and exclusion criteria, as described previously [24,25]. In brief, 166 controls and 154 breast cancer patients between the ages of 25-65 years were recruited for this study. Cases and controls were from the same ethnic group and were residents of northern parts of India. Patients were classified in premenopausal and postmenopausal groups on the basis of clinical history and information given by them. The medical ethics committees of the concerned institutions approved the study. A written pre-informed consent was obtained prior to blood collection from the individuals involved in this study.

Blood was drawn through venous puncture from controls and breast cancer patients and collected in vials containing tri sodium citrate $(3.8 \%$; 9:1 v/v; pH 6.5) and genomic DNA was extracted [25, 26]. Genotyping of CYP1B1 Leu432Val and COMT Val108/158Met polymorphisms were performed employing polymerase chain reaction-restriction fragment length polymorphism (PCR-RFLP) followed by gel electrophoresis. PCR primers were designed and amplification was performed, as reported elsewhere [7]. The desired segment of CYP1B1 and COMT genes was amplified using optimal conditions of amplification (Mastercycler gradient thermocycler, Eppendorf, Germany). The reported forward (5'CACTGCCAACACCTCTGTCT3') and reverse (5'GCAGGCTCATTTGGGTTG3') primers were used to amplify the desired segment of CYP1B1 gene. Similarly, the reported forward (5'ACTGTGGCTACTCAGCTGTG3') and reverse (5'CCTTTTTCCAGGTCTGACAAC3') primers were also used to amplify the desired segment of COMT gene. In brief, the PCR amplification reaction was performed in $25 \mu \mathrm{l}$ of assay mixture, containing genomic DNA (100 ng), 10x buffer (2.5 $\mu \mathrm{l})$, MgCl2 (15 mM), dNTPs (0.16 mM each), Hot Start Taq DNA polymerase (1.5U) (Fermentas, Canada) and 
forward and reverse primers (20 pM each) (Hysel, India). The reaction mixture was initially denatured at $94^{\circ} \mathrm{C}$ for $15 \mathrm{~min}$, followed by 35 cycles of denaturation at $94^{\circ} \mathrm{C}$ for $45 \mathrm{sec}$. The annealing temperature was $60^{\circ} \mathrm{C}$ for CYP1B1 for $45 \mathrm{sec}$ and $65^{\circ} \mathrm{C}$ for COMT for $45 \mathrm{sec}$. Final extension temperature for both genes was $72^{\circ} \mathrm{C}$ for $45 \mathrm{sec}$.

PCR amplicon of CYP1B1 was digested with Eco57I restriction endonuclease (Fermentas, Canada) at $37^{\circ} \mathrm{C}$ for $16 \mathrm{~h}$. The digested sizes of the fragments were $187 \mathrm{bp}$ and $107 \mathrm{bp}$ in wild type, 294bp in homozygous variant and 187bp, 107bp and 294bp in heterozygous variant. The PCR amplicon of COMT was digested with NlaIII at $37^{\circ} \mathrm{C}$ for $16 \mathrm{~h}$. The digested sizes of the fragments were $114 \mathrm{bp}, 29 \mathrm{bp}$ and $26 \mathrm{bp}$ in wild type, 96bp, 29bp, 26bp, 18bp in homozygous variant and $114 \mathrm{bp}, 96 \mathrm{bp}, 29 \mathrm{bp}, 26 \mathrm{bp}$ and 18bp in heterozygous variant.

The PCR amplicon of CYP1B1 and its digested products were resolved in $1.5 \%$ agarose gel. COMT and its digested products were resolved in $12 \%$ polyacrylamide gel. Ethidium bromide using UV transilluminator visualized the bands.

\subsection{Clinical and pathological information}

The mean ages of premenopausal patients and controls were $40.41 \pm 0.82$ and $32.60 \pm 0.60$ years and postmenopausal patients and controls were $53.72 \pm$ 0.93 and $52.50 \pm 0.88$ years respectively. The average ages of menarche were $13.75 \pm 0.09$ years in patients and $13.70 \pm 0.05$ years in controls. The average body mass indexes of patients and controls in terms of $\mathrm{Kg} / \mathrm{m}^{2}$ were $25.31 \pm 0.42$ and $20.20 \pm$ 0.20 respectively. Among selected subjects, 59 patients $(38.31 \%)$ and 99 controls $(59.64 \%)$ were premenopausal and 95 patients $(61.69 \%)$ and 67 controls (40.36\%) were postmenopausal women. Mostly nonsmokers samples could be collected, as females in Indian population rarely possess smoking habit. The numbers of non-smokers were 149 in cases $(96.76 \%)$ and 160 in controls $(96.39 \%)$. The tumor was diagnosed at first stage in 6 patients, second stage in 78 patients and third stage in 70 patients. Among diagnosed patients, radiotherapy was given to total $117(75.97 \%)$, neo-adjuvant chemotherapy to $34(22.08 \%)$, tamoxifen therapy to $29(18.84 \%)$ and chemotherapy to 112 $(72.72 \%)$ individuals. Surgery was performed in 136 subjects $(88.31 \%)$ at some or other stages. The lobular tumor was identified in 4 patients, ductal in 146 patients and mixed/unclassified in 4 patients. The nodal
Table 1

Clinical information of cases and controls

\begin{tabular}{|c|c|c|}
\hline \multicolumn{3}{|l|}{ Age (Years) } \\
\hline Premenopausal & $40.41 \pm 0.82$ & $32.60 \pm 0.60$ \\
\hline Postmenopausal & $53.72 \pm 0.93$ & $52.50 \pm 0.88$ \\
\hline Menarche age & $13.75 \pm 0.087$ & $13.70 \pm 0.053$ \\
\hline \multicolumn{3}{|c|}{ Menopausal status (Number) } \\
\hline Premenopausal & 59 & 99 \\
\hline Postmenopausal & 95 & 67 \\
\hline \multicolumn{3}{|l|}{ Stage (Number) } \\
\hline$\leqslant$ Stage I & 06 & \\
\hline Stage II & 78 & \\
\hline$\geqslant$ Stage III & 70 & \\
\hline \multicolumn{3}{|l|}{ Type } \\
\hline Tumour of duct & 146 & \\
\hline Tumour of lobule & 04 & \\
\hline Unclassified & 04 & \\
\hline \multicolumn{3}{|l|}{ Nodal status } \\
\hline+ & 102 & \\
\hline- & 52 & \\
\hline \multicolumn{3}{|l|}{ Surgery } \\
\hline+ & 136 & \\
\hline- & 18 & \\
\hline \multicolumn{3}{|l|}{ Chemotherapy } \\
\hline+ & 112 & \\
\hline- & 42 & \\
\hline \multicolumn{3}{|l|}{ Tamoxifen therapy } \\
\hline+ & 29 & \\
\hline- & 125 & \\
\hline \multicolumn{3}{|c|}{ Neo-adjuvant chemotherapy } \\
\hline+ & 34 & \\
\hline- & 120 & \\
\hline \multicolumn{3}{|l|}{ Radiotherapy } \\
\hline+ & 117 & \\
\hline- & 37 & \\
\hline
\end{tabular}

status of tumors was detected positive in 102 patients $(66.23 \%)$ and negative in 52 patients $(33.77 \%)$ [Table 1]. The lymph node status was identified either by surgical resection or by fine needle aspiration cytology (FNAC) [27].

\subsection{Statistical analysis}

Allelic and genotypic frequencies were calculated; unadjusted odds ratio (OR) was calculated by $2 \times 2$ contingency table with $95 \%$ confidence intervals and statistical significance for OR was calculated using the chi-square test using Epi Info-5 software. Fisher exact test was used, when expected cell frequency was less than five. Minimum detectable OR with $80 \%$ power significance level (0.05) and 100 samples each in cases and controls with prevailing percent of homozygous wild type in controls were considered 0.5 in case of protective association and 2.0 in case of increased risk [28]. The data presented for the study were not corrected for multiple testing as correction bares the risk to ignore important findings and the ex- 
Table 2

Allelic and genotypic frequencies of CYP1B1 polymorphism in Indian female breast cancer patients and controls considered for analysis

\begin{tabular}{|c|c|c|c|c|}
\hline & $\begin{array}{l}\text { Patients } \\
n=154\end{array}$ & $\begin{array}{c}\text { Case controls } \\
n=166\end{array}$ & Odds Ratio $(95 \% \mathrm{CI})$ & p-value \\
\hline \multicolumn{5}{|c|}{ Total women } \\
\hline \multicolumn{5}{|c|}{ Allele frequency (number of alleles) } \\
\hline $\mathrm{C}$ & $0.68(208)$ & $0.69(229)$ & 1.0 (reference) & \\
\hline G & $0.32(100)$ & $0.31(103)$ & $1.07(0.76-1.51)$ & 0.758 \\
\hline \multicolumn{5}{|c|}{ Genotypic frequency (number of genotypes) } \\
\hline $\mathrm{C} / \mathrm{C}$ & $0.45(69)$ & $0.42(69)$ & 1.0 (reference) & \\
\hline $\mathrm{C} / \mathrm{G}$ & $0.45(70)$ & $0.55(91)$ & $0.77(0.47-1.25)$ & 0.312 \\
\hline $\mathrm{G} / \mathrm{G}$ & $0.10(15)$ & $0.03(6)$ & $2.50(0.85-8.30)$ & 0.110 \\
\hline $\mathrm{C} / \mathrm{G}+\mathrm{G} / \mathrm{G}$ & $0.55(85)$ & $0.58(97)$ & $0.88(0.55-1.40)$ & 0.637 \\
\hline Premenopausal women & $n=59$ & $n=99$ & & \\
\hline \multicolumn{5}{|c|}{ Allele frequency (number of alleles) } \\
\hline $\mathrm{C}$ & $0.71(84)$ & $0.70(140)$ & 1.0 (reference) & \\
\hline G & $0.29(34)$ & $0.30(58)$ & $0.98(0.57-1.66)$ & 0.970 \\
\hline \multicolumn{5}{|c|}{ Genotypic frequency (number of genotypes) } \\
\hline $\mathrm{C} / \mathrm{C}$ & $0.53(31)$ & $0.44(44)$ & 1.0 (reference) & \\
\hline $\mathrm{C} / \mathrm{G}$ & $0.37(22)$ & $0.53(52)$ & $0.60(0.29-1.25)$ & 0.190 \\
\hline $\mathrm{G} / \mathrm{G}$ & $0.10(6)$ & $0.03(3)$ & $2.84(0.55-18.65)$ & 0.173 \\
\hline $\mathrm{C} / \mathrm{G}+\mathrm{G} / \mathrm{G}$ & $0.47(28)$ & $0.56(55)$ & $0.72(0.36-1.45)$ & 0.411 \\
\hline Postmenopausal women & $n=95$ & $n=67$ & & \\
\hline \multicolumn{5}{|c|}{ Allele frequency (number of alleles) } \\
\hline $\mathrm{C}$ & $0.65(124)$ & $0.66(89)$ & 1.0 (reference) & \\
\hline G & $0.35(66)$ & $0.34(45)$ & $1.05(0.64-1.72)$ & 0.922 \\
\hline \multicolumn{5}{|c|}{ Genotypic frequency (number of genotypes) } \\
\hline $\mathrm{C} / \mathrm{C}$ & $0.40(38)$ & $0.37(25)$ & 1.0 (reference) & \\
\hline $\mathrm{C} / \mathrm{G}$ & $0.51(48)$ & $0.58(39)$ & $0.81(0.40-1.65)$ & 0.644 \\
\hline $\mathrm{G} / \mathrm{G}$ & $0.09(9)$ & $0.04(3)$ & $1.97(0.43-12.33)$ & 0.517 \\
\hline $\mathrm{C} / \mathrm{G}+\mathrm{G} / \mathrm{G}$ & $0.60(57)$ & $0.63(42)$ & $0.89(0.45-1.78)$ & 0.855 \\
\hline
\end{tabular}

ploratory character of the study. Hardy-Weinberg equilibrium genotypic frequencies were calculated using Hardy-Weinberg calculator (http://www.genes.org.uk/ software/hardy-weinberg.shtml).

\section{Results}

\subsection{Allelic and genotypic frequency of $C / G$ in $C Y P$ IBl gene ( Leu $\left.^{432} \mathrm{Val}\right)$}

Although lack of statistically significant protection or risk was seen in total, premenopausal or postmenopausal women as compared with respective controls on the basis of probability score, the frequencies of $\mathrm{C}$ allele [68.5\%; 71.5\% and 64.5\%] were approximately twice as compared with $\mathrm{G}$ allele $[31.5 \% ; 29.5 \%$ and $36.5 \%$ ]. Similarly, genotypic frequency of G/G homozygous was $2-3$ folds higher in patients $[10 \% ; 10 \%$ and $9 \%$ ] of all the groups as compared with respective controls [3\%; 3\% and 4\%] (Table 2). Polymorphisms of CYP1B1 in estrogen receptor positive and estrogen receptor negative breast cancer patients were also analyzed separately (data not shown), but no statistically significant difference was observed. The patterns of association were similar as observed with total breast cancer patients.

\subsection{Allelic and genotypic frequency of G/A in COMT gene $\left(\right.$ Val $\left.^{158} \mathrm{Met}\right)$}

The frequency of G allele (62\%) was higher as compared with A in premenopausal women; however, no statistically significant change was observed in total and postmenopausal women (Table 3 ).

\subsection{Hardy-weinberg equilibrium}

The genotypic frequencies for each SNP in cases and controls did not show statistically significant deviation from expected frequencies except for CYP1B1. The observed genotypic frequencies of COMT G/G, G/A and $\mathrm{A} / \mathrm{A}$ in cases and controls did not show statistically significant deviation from expected frequencies. The observed genotypic frequencies of CYP1B1 C/C, C/G and $\mathrm{G} / \mathrm{G}$ in total, premenopausal and postmenopausal patients also did not show significant deviation from expected frequencies, however, significant deviation was 
Table 3

Allelic and genotypic frequencies of COMT polymorphism in Indian female breast cancer patients and controls considered for analysis

\begin{tabular}{|c|c|c|c|c|}
\hline & $\begin{array}{l}\text { Patients } \\
n=154\end{array}$ & $\begin{array}{c}\text { Case controls } \\
n=166\end{array}$ & Odds Ratio (95\%CI) & p-value \\
\hline \multicolumn{5}{|c|}{ Total women } \\
\hline \multicolumn{5}{|c|}{ Allele frequency (number of alleles) } \\
\hline $\mathrm{G}$ & $0.55(170)$ & $0.57(189)$ & 1.0 (reference) & \\
\hline A & $0.45(138)$ & $0.43(143)$ & $1.07(0.78-1.48)$ & 0.717 \\
\hline \multicolumn{5}{|c|}{ Genotypic frequency (number of genotypes) } \\
\hline $\mathrm{G} / \mathrm{G}$ & $0.29(44)$ & $0.32(52)$ & 1.0 (reference) & \\
\hline G/A & $0.53(82)$ & $0.51(85)$ & $1.14(0.67-1.95)$ & 0.701 \\
\hline $\mathrm{A} / \mathrm{A}$ & $0.18(28)$ & $0.17(29)$ & $1.14(0.56-2.32)$ & 0.820 \\
\hline $\mathrm{G} / \mathrm{A}+\mathrm{A} / \mathrm{A}$ & $0.71(110)$ & $0.68(114)$ & $1.14(0.69-1.89)$ & 0.678 \\
\hline Premenopausal women & $n=59$ & $n=99$ & & \\
\hline \multicolumn{5}{|c|}{ Allele frequency (number of alleles) } \\
\hline $\mathrm{G}$ & $0.64(76)$ & $0.60(117)$ & 1.0 (reference) & \\
\hline A & $0.36(42)$ & $0.40(81)$ & $0.80(0.48-1.31)$ & 0.413 \\
\hline \multicolumn{5}{|c|}{ Genotypic frequency (number of genotypes) } \\
\hline $\mathrm{G} / \mathrm{G}$ & $0.39(23)$ & $0.33(32)$ & 1.0 (reference) & \\
\hline $\mathrm{G} / \mathrm{A}$ & $0.51(30)$ & $0.53(53)$ & $0.79(0.37-1.68)$ & 0.622 \\
\hline $\mathrm{A} / \mathrm{A}$ & $0.10(6)$ & $0.14(14)$ & $0.60(0.16-1.98)$ & 0.508 \\
\hline $\mathrm{G} / \mathrm{A}+\mathrm{A} / \mathrm{A}$ & $0.61(36)$ & $0.67(67)$ & $0.75(0.36-1.55)$ & 0.498 \\
\hline Postmenopausal women & $n=95$ & $n=67$ & & \\
\hline \multicolumn{5}{|c|}{ Allele frequency (number of alleles) } \\
\hline $\mathrm{G}$ & $0.49(94)$ & $0.54(72)$ & 1.0 (reference) & \\
\hline A & $0.51(96)$ & $0.46(62)$ & $1.19(0.74-1.89)$ & 0.520 \\
\hline \multicolumn{5}{|c|}{ Genotypic frequency (number of genotypes) } \\
\hline $\mathrm{G} / \mathrm{G}$ & $0.22(21)$ & $0.30(20)$ & 1.0 (reference) & \\
\hline G/A & $0.55(52)$ & $0.48(32)$ & $1.55(0.68-3.53)$ & 0.345 \\
\hline $\mathrm{A} / \mathrm{A}$ & $0.23(22)$ & $0.22(15)$ & $1.40(0.52-3.79)$ & 0.615 \\
\hline $\mathrm{G} / \mathrm{A}+\mathrm{A} / \mathrm{A}$ & $0.78(74)$ & $0.70(47)$ & $1.50(0.69-3.25)$ & 0.350 \\
\hline
\end{tabular}

observed for CYP1B1 C/C, C/G and G/G genotypes in total ( $\mathrm{p}$ value $=0.0003$ ), premenopausal ( $\mathrm{p}$ value $=$ 0.0077 and postmenopausal ( $\mathrm{p}$ value $=0.0126$ ) controls. The significant deviation of control group from equilibrium could be due to variability of environmental conditions, life style and food habits of Indian women and could play a role in offering protection against breast cancer in Indian women.

\subsection{Association of COMT (Val ${ }^{158}$ Met) and CYP1B1 $\left(\mathrm{Leu}^{432} \mathrm{Val}\right)$ polymorphisms in combination}

It was observed that homozygous wild type (G/G) of COMT and CYP1B1 heterozygous variant $(\mathrm{C} / \mathrm{G})$ in combination exhibited a significant protection against breast cancer risk in total and premenopausal women $[\mathrm{OR}=0.29 ; 95 \% \mathrm{CI}, 0.11-0.76$, $\mathrm{p}$ value $=0.009$ and $\mathrm{OR}=0.21 ; 95 \% \mathrm{CI}, 0.05-0.82 ; p=0.021]$. COMT G/A heterozygous variant in combination with CYP1B1 wild C/C showed significant protective association in premenopausal women $[\mathrm{OR}=0.29 ; 95 \%$ $\mathrm{CI}, 0.08-0.96$, $\mathrm{p}$ value $=0.042]$. Homozygous variant (A/A) of COMT and CYP1B1 heterozygous variant $(\mathrm{C} / \mathrm{G})$ in combination exhibited a trend of protection al- though not statistically significant against breast cancer risk in premenopausal women $[\mathrm{OR}=0.15 ; 95 \% \mathrm{CI}$, $0.01-1.11, \mathrm{p}$ value $=0.054]$ (Table 4$)$. The association patterns of COMT polymorphism between estrogen receptor positive and estrogen receptor negative breast cancer patients did not exhibit statistically significant change, when analyzed separately (data not shown). The patterns of association were statistically similar as observed with total breast cancer patients.

\section{Discussion}

Substitution of Leu to Val in CYP1B1 increases its catalytic activity by 2.4-3.4 folds, while Val to Met substitution in COMT decreases its catalytic activity of COMT by 2 to 3 fold. In this study, the polymorphisms of COMT (Val ${ }^{158} \mathrm{Met}$ ) and CYP1B1 (Leu $\left.{ }^{432} \mathrm{Val}\right)$ genes were performed to assess their contribution in the breast cancer risk in Indian women. Although such studies have been performed in some populations globally [7, 29-34], keeping into consideration of the variability in food habit, life style, environmental exposure and ethnicity $[23,24]$, it was worthwhile to perform such study in Indian women. 
Table 4

Combinational genotypic frequencies of COMT and CYP1B1 polymorphism in Indian female breast cancer patients and controls considered for analysis. Former genotype given in table indicates COMT and later CYP1B1

\begin{tabular}{|c|c|c|c|c|}
\hline & $\begin{array}{c}\text { Patients } \\
n=154\end{array}$ & $\begin{array}{c}\text { Case controls } \\
n=166\end{array}$ & Odds Ratio (95\%CI) & p-value \\
\hline \multicolumn{5}{|l|}{ Total women } \\
\hline \multicolumn{5}{|c|}{ Genotypic frequency (number of genotypes) } \\
\hline $\mathrm{G} / \mathrm{G}, \mathrm{C} / \mathrm{C}$ & $0.15(23)$ & $0.09(15)$ & 1.0 (reference) & - \\
\hline $\mathrm{G} / \mathrm{G}, \mathrm{C} / \mathrm{G}$ & $0.10(16)$ & $0.22(36)$ & $0.29(0.11-0.76)$ & 0.009 \\
\hline $\mathrm{G} / \mathrm{G}, \mathrm{G} / \mathrm{G}$ & $0.04(5)$ & $0.01(1)$ & $3.26(0.31-164.34)$ & 0.392 \\
\hline $\mathrm{G} / \mathrm{A}, \mathrm{C} / \mathrm{C}$ & $0.21(32)$ & $0.26(43)$ & $0.49(0.20-1.16)$ & 0.110 \\
\hline $\mathrm{G} / \mathrm{A}, \mathrm{C} / \mathrm{G}$ & $0.26(40)$ & $0.23(39)$ & $0.67(0.28-1.57)$ & 0.419 \\
\hline $\mathrm{G} / \mathrm{A}, \mathrm{G} / \mathrm{G}$ & $0.06(10)$ & $0.02(3)$ & $2.17(0.45-14.1)$ & 0.336 \\
\hline $\mathrm{A} / \mathrm{A}, \mathrm{C} / \mathrm{C}$ & $0.09(14)$ & $0.07(11)$ & $0.83(0.26-2.61)$ & 0.924 \\
\hline $\mathrm{A} / \mathrm{A}, \mathrm{C} / \mathrm{G}$ & $0.09(14)$ & $0.10(16)$ & $0.57(0.19-1.67)$ & 0.371 \\
\hline $\mathrm{A} / \mathrm{A}, \mathrm{G} / \mathrm{G}$ & $00(0)$ & $0.01(2)$ & - & - \\
\hline Premenopausal women & $n=59$ & $n=99$ & & \\
\hline \multicolumn{5}{|c|}{ Genotypic frequency (number of genotypes) } \\
\hline $\mathrm{G} / \mathrm{G}, \mathrm{C} / \mathrm{C}$ & $0.22(13)$ & $0.08(8)$ & 1.0 (reference) & \\
\hline $\mathrm{G} / \mathrm{G}, \mathrm{C} / \mathrm{G}$ & $0.14(8)$ & $0.23(23)$ & $0.21(0.05-0.82)$ & 0.021 \\
\hline $\mathrm{G} / \mathrm{G}, \mathrm{G} / \mathrm{G}$ & $0.03(2)$ & $0.01(1)$ & $1.23(0.05-81.57)$ & 1.000 \\
\hline $\mathrm{G} / \mathrm{A}, \mathrm{C} / \mathrm{C}$ & $0.24(14)$ & $0.30(30)$ & $0.29(0.08-0.96)$ & 0.042 \\
\hline $\mathrm{G} / \mathrm{A}, \mathrm{C} / \mathrm{G}$ & $0.20(12)$ & $0.21(21)$ & $0.35(0.10-1.25)$ & 0.120 \\
\hline G/A, G/G & $0.07(4)$ & $0.02(2)$ & $1.23(0.14-16.47)$ & 1.000 \\
\hline $\mathrm{A} / \mathrm{A}, \mathrm{C} / \mathrm{C}$ & $0.07(4)$ & $0.06(6)$ & $0.41(0.07-2.44)$ & 0.441 \\
\hline $\mathrm{A} / \mathrm{A}, \mathrm{C} / \mathrm{G}$ & $0.03(2)$ & $0.08(8)$ & $0.15(0.01-1.11)$ & 0.054 \\
\hline $\mathrm{A} / \mathrm{A}, \mathrm{G} / \mathrm{G}$ & $00(0)$ & $00(0)$ & - & - \\
\hline Postmenopausal women & $n=95$ & $n=67$ & & \\
\hline \multicolumn{5}{|c|}{ Genotypic frequency (number of genotypes) } \\
\hline $\mathrm{G} / \mathrm{G}, \mathrm{C} / \mathrm{C}$ & $0.11(10)$ & $0.10(7)$ & 1.0 (reference) & \\
\hline $\mathrm{G} / \mathrm{G}, \mathrm{C} / \mathrm{G}$ & $0.08(8)$ & $0.20(13)$ & $0.43(0.09-1.92)$ & 0.344 \\
\hline $\mathrm{G} / \mathrm{G}, \mathrm{G} / \mathrm{G}$ & $0.03(3)$ & $00(0)$ & - & - \\
\hline $\mathrm{G} / \mathrm{A}, \mathrm{C} / \mathrm{C}$ & $0.19(18)$ & $0.20(13)$ & $0.97(0.25-3.79)$ & 0.799 \\
\hline $\mathrm{G} / \mathrm{A}, \mathrm{C} / \mathrm{G}$ & $0.29(28)$ & $0.27(18)$ & $1.09(0.30-3.88)$ & 0.886 \\
\hline $\mathrm{G} / \mathrm{A}, \mathrm{G} / \mathrm{G}$ & $0.06(6)$ & $0.01(1)$ & $4.20(0.35-220.30)$ & 0.352 \\
\hline $\mathrm{A} / \mathrm{A}, \mathrm{C} / \mathrm{C}$ & $0.11(10)$ & $0.07(5)$ & $1.40(0.26-7.59)$ & 0.927 \\
\hline $\mathrm{A} / \mathrm{A}, \mathrm{C} / \mathrm{G}$ & $0.13(12)$ & $0.12(8)$ & $1.05(0.23-4.79)$ & 0.792 \\
\hline $\mathrm{A} / \mathrm{A}, \mathrm{G} / \mathrm{G}$ & $00(0)$ & $0.03(2)$ & - & - \\
\hline
\end{tabular}

Although lack of significant association with individual genotype was observed in total, premenopausal or postmenopausal women, the genotypic frequency of CYP1B1 G/G homozygous was 2-3 folds higher in patients as compared with respective controls. The absence of significant association with breast cancer in Indian women is contrary to Caucasian, English, Swedish and Turkish populations, where either positive or negative associations with breast cancer risk are reported [29,30,32]. The frequency of $\mathrm{C}$ allele was found higher in Indian women as compared with $\mathrm{G}$ allele. This is in accordance with American Caucasians but higher than that of Chinese [35,36]. The higher frequency of $\mathrm{C}$ allele was also observed in premenopausal Indian women, as observed in Turkish and Chinese [7, 32]. The frequency of $\mathrm{C} / \mathrm{G}$ genotype in Indian patients exhibited almost similar pattern as observed in African American and Caucasian American but lower than Chi- nese and higher than Turkish and Taiwanese [7,31,32, 35].

The frequency of $\mathrm{G}$ allele (62\%) in COMT was slightly higher in premenopausal women, as observed in other Asians [37] but contrary to Caucasians [38]. However, lack of statistically significant difference was noted in the frequency of alleles-G and A both in total and postmenopausal women as observed in Finnish women [39].

COMT wild type and CYP1B1 heterozygous variant in combination exhibited significant protection against breast cancer risk in total and premenopausal women. COMT homozygous variant and CYP1B1 heterozygous variant in combination also exhibited a significant protection against breast cancer risk in premenopausal women. The protective association in premenopausal women could be a compensatory phenomenon that regulates the accumulation of toxic metabolites under the conditions of increased 4-hydroxylation and decreased 
methyl transfer reactions, as Leu to Val substitution in CYP1B1 increases its catalytic activity and substitution of Val to Met at codon 158 decreases the catalytic activity of COMT [20,33,34]. Combination of increase in 4-hydroxylation activity and decrease in COMT activity could be important to protect premenopausal women with breast cancer susceptibility. In postmenopausal Indian women, polymorphisms in estrogen-metabolizing genes possibly do not play important role, as reported in many other populations [6, 7,29-32] due to variable life style, environmental exposure and ethnicity of Indians.

In conclusion, the results demonstrate that individually COMT or CYP1B1 polymorphism may not be very important contributors; in combination they may act as important determinants of breast cancer incidences among premenopausal Indian women.

\section{Acknowledgements}

Authors sincerely thank Council of Scientific and Industrial Research, New Delhi for providing research fellowship to Sharawan Yadav and University Grant Commission, New Delhi to Naveen Kumar Singhal and Virendra Singh. The IITR Communication number of this article is 2757 .

\section{References}

[1] S.E. Hankinson, W.C. Willett, J.E. Manson G.A. Colditz, D.J. Hunter, D. Spiegelman, R.L. Barbieri and F.E. Speizer, Plasma sex steroid hormone levels and risk of breast cancer in postmenopausal women, J Natl Cancer Inst 90 (1999), 12921299.

[2] E.A. Mady, E.E. Ramadan and A.A. Ossman, Sex steroid hormones in serum and tissue of benign and malignant breast tumor patients, Dis Markers 16 (2000), 151-157.

[3] L.M. Morimoto, E. White, Z. Chen, R.T. Chlebowski, J. Hays, L. Kuller, A.M. Lopez, J. Manson, K.L. Margolis, P.C. Muti, M.L. Stefanick and A. McTiernan, Obesity, body size, and risk of postmenopausal breast cancer: the women's health initiative (United States), Cancer Causes Control 13 (2002), 741-751.

[4] S.S. Coughlin and M. Piper, Genetic polymorphisms and risk of breast cancer, Cancer Epidemiol Biomarkers Prev 8 (1999), 1023-1032.

[5] A.M. Dunning, C.S. Healey, P.D. Pharoah, M.D. Teare, B.A. Ponder and D.F. Easton. A systematic review of genetic polymorphisms and breast cancer risk, Cancer Epidemiol Biomark Prev 8 (1999), 843-854.

[6] V.N. Kristensen and A.L. Borresen-Dale, Molecular epidemiology of breast cancer: genetic variation in steroid hormone metabolism, Mutat Res 462 (2000), 323-333.
[7] W. Wen, Q. Cai, X.O. Shu, C. Jia-Rong, F. Parl, L. Pierce, Y.T. Gao and W. Zheng, Cytochrome P450 1B1 and catechol-Omethyltransferase genetic polymorphisms and breast cancer risk in Chinese women: results from the Shanghai breast cancer study and a meta-analysis, Cancer Epidemiol Biomarkers Prev 14 (2005), 329-335.

[8] V. Paracchini, S. Raimondi, I.T. Gram, D. Kang, N.A. Kocabas, V.N. Kristensen, D. Li, F.F. Parl, T. Rylander-Rudqvist, P. Soucek, W. Zheng, S. Wedren and E. Taioli. Meta- and pooled analyses of the cytochrome P-450 1B1 Val432Leu polymorphism and breast cancer: a HuGE-GSEC review, Am J Epidemiol 165 (2007), 115-125.

[9] T.R. Sutter, Y.M. Tang, C.L. Hayes, Y.Y. Wo, E.W. Jabs, X. Li, H. Yin, C.W. Cody and W.F. Greenlee, Complete cDNA sequence of a human dioxin-inducible mRNA identifies a new gene subfamily of cytochrome $\mathrm{P} 450$ that maps to chromosome 2, J Biol Chem 269 (1994), 13092-13099.

[10] Y.M. Tang, Y.Y. Wo, J. Stewart, A.L. Hawkins, C.A. Griffin, T.R. Sutter and W.F. Greenlee, Isolation and characterization of the human cytochrome P450 CYP1B1 gene, J Biol Chem 271 (1996), 28324-28330.

[11] M.H. Grossman, B.S. Emanueal and M.L. Budarf, Chromosomal mapping of the human catechol- $O$-methyltransferase gene to 22q11.1-q11.2, Genomics 12 (1992), 822-825.

[12] K. Lundstrom, M. Salminen, A. Jalanko, K. Savolainen and I. Ulmanen, Cloning, expression and structure of catechol- $O$ methyltransferase, Biochim Biophys Acta 1251 (1995), 1-10.

[13] J. Tenhunen, M. Salminen, A. Jalanko, S. Ukkonen and I. Ulmanen, Structure of the rat catechol- $O$-methyltransferase gene: separate promoters are used to produce mRNAs for soluble and membrane-bound forms of the enzyme, DNA Cell Biol 12 (1993), 253-263.

[14] J. Tenhunen, M. Salminen, K. Lundström, T. Kiviluoto, R. Savolainen and I. Ulmanen, Genomic organization of the human catechol-O-methyltransferase gene and its expression from two distinct promoters, Eur J Biochem 223 (1994), 10491059.

[15] C.L. Hayes, D C Spink, B C Spink, J Q Cao, N J Walker and T R Sutter, 17 beta-estradiol hydroxylation catalyzed by human cytochrome P450 1B1, Proc Natl Acad Sci USA 93 (1996), 9776-9781.

[16] J.D. Yager and J.G. Liehr, Molecular mechanisms of estrogen carcinogenesis, Annu Rev Pharmacol Toxicol 36 (1996), 203232.

[17] B.T. Zhu and A.H. Conney, Is 2-methoxyestradiol an endogenous estrogen metabolite that inhibits mammary carcinogenesis, Cancer Res 58 (1998), 2269-2277.

[18] B.T. Zhu, Medical hypothesis: hyperhomocysteinemia is a risk factor for estrogen-induced hormonal cancer, Int J Oncol 22 (2003), 499-508.

[19] J.J. Li and S.A. Li, Estrogen carcinogenesis in Syrian hamster tissues: role of metabolism, Fed Proc 46 (1987), 1858-1863.

[20] T. Shimada, J. Watanabe, K. Kawajiri, T.R. Sutter, F.P. Guengerich, E.M.J. Gillam and K. Inoue, Catalytic properties of polymorphic human cytochrome P450 1B1 variants, Carcinogenesis 20 (1999), 1607-1613.

[21] E. Aklillu, M. Oscarson, M. Hidestrand, B. Leidvik, C. Otter and M. Ingelman-Sundberg, Functional analysis of six different polymorphic CYP1B1 enzyme variants found in an Ethiopian population, Mol Pharmacol 61 (2002), 586-594.

[22] S. Dawling, N. Roodi, R.L. Mernaugh, X. Wang and F.F. Parl, Catechol-O-methyltransferase (COMT)-mediated metabolism of catechol estrogens: comparison of wild-type 
and variant COMT isoforms, Cancer Res 61 (2001), 67166722.

[23] T. Rastogi, A. Hildesheim and R. Sinha, Opportunities for cancer epidemiology in developing countries, Nat Rev Cancer 4 (2004), 909-917.

[24] V. Singh, N. Rastogi, N. Mathur, K. Singh and M.P. Singh, Association of polymorphism in MDM-2 and p53 genes with breast cancer risk in Indian women, Ann Epidemiol 18 (2008), $48-57$.

[25] V. Singh, N. Rastogi, A. Sinha, A. Kumar, N. Mathur and M.P. Singh, A study on the association of cytochrome-P450 1A1 polymorphism and breast cancer risk in north Indian women, Breast Cancer Res Treat 101 (2007), 73-81.

[26] S.A. Miller, D.D. Dykes and H.F. Polesky, A simple salting out procedure for extracting DNA from human nucleated cells, Nucleic Acids Res 16 (1988), 1215.

[27] G. Suman, K. Jamil, K. Suseela and M.C. Vamsy, Novel mutations of CYP3A4 in fine needle aspiration cytology samples of breast cancer patients and its clinical correlations, Cancer Biomark 5 (2009), 33-40.

[28] J.L. Fleiss, Statistical Methods for Rates and Proportion, 2nd ed., Wiley-Liss Inc, New York, 1981, pp. 38-45.

[29] A.M. Dunning, M. Dowsett, C.S. Healey, L. Tee, R.N. Luben, E. Folkerd, K.L. Novik, L. Kelemen, S. Ogata, P.D.P. Pharoah, D.F. Easton, N. E. Day and B.A. J. Ponder, Polymorphisms associated with circulating sex hormone levels in postmenopausal women, J Natl Cancer Inst 96 (2004), 936-945.

[30] T. Rylander-Rudqvist, S. Wedren, F. Granath, K. Humphreys, S. Ahlberg, E. Weiderpass, M. Oscarson, M. IngelmanSundberg and I. Persson, Cytochrome P450 1B1 gene polymorphisms and postmenopausal breast cancer risk, Carcinogenesis 24 (2003), 1533-1539.

[31] K.M. Lee, J. Abel, Y. Ko, V. Harth, W.Y. Park, J.S. Seo, K.Y. Yoo, J.Y. Choi, A. Shin, S.H. Ahn, D.Y. Noh, A. Hirvonen and D. Kang, Genetic polymorphisms of cytochrome P450 19 and 1B1, alcohol use, and breast cancer risk in Korean women,
Br J Cancer 88 (2003), 675-678.

[32] N.A. Kocabas, S. Sardas, S. Cholerton, A.K. Daly and A.E. Karakaya, Cytochrome P450 CYP1B1 and catechol-Omethyltransferase (COMT) genetic polymorphisms and breast cancer susceptibility in a Turkish population, Arch Toxicol $\mathbf{7 6}$ (2002), 643-649.

[33] I.H. Hanna, S. Dawling, N. Roodi, F.P. Guengerich and F.F. Parl, Cytochrome P450 1B1 (CYP1B1) pharmacogenetics: association of polymorphisms with functional differences in estrogen hydroxylation activity, Cancer Res 60 (2000), 34403444.

[34] H.C. Guldberg and C.A. Marsden, Catechol-O-methyl transferase: pharmacological aspects and physiological role, Pharmacol Rev 7 (1975), 419-424.

[35] L.R. Bailey, N. Roodi, W.D. Dupont and F.F. Parl, Association of cytochrome P450 1B1 (CYP1B1) polymorphism with steroid receptor status in breast cancer, Cancer Res $\mathbf{5 8}$ (1998), 5038-5041.

[36] W. Zheng, D.W. Xie, F. Jin, J.R. Cheng, Q. Dai, W.Q. Wen, X.O. Shu and Y.T. Gao, Genetic polymorphism of cytochrome P450-1B1 and risk of breast cancer, Cancer Epidemiol Biomarkers Prev 9 (2000), 147-150.

[37] A.H. Wu, C.C. Tseng, D. Vandenberg and M.C. Yu, Tea intake, COMT genotype, and breast cancer in Asian-American women, Cancer Res 63 (2003), 7526-7529.

[38] J.A. Lavigne, K.J. Helzlsouer, H.Y. Huang, P.T. Strickland, D.A. Bell, O. Selmin, M.A. Watson, S. Hoffman, G.W. Comstock and J.D. Yager, An association between the allele coding for a low activity variant of catechol-O-methyltransferase and the risk for breast cancer, Cancer Res 57 (1997), 5493-5497.

[39] K. Mitrunen, N. Jourenkova, V. Kataja, M. Eskelinen, V.M. Kosma, S. Benhamou, D. Kang, H. Vainio, M. Uusitupa and A. Hirvonen, Polymorphic catechol-O-methyltransferase gene and breast cancer risk, Cancer Epidemiol Biomarkers Prev 10 (2001), 635-640. 


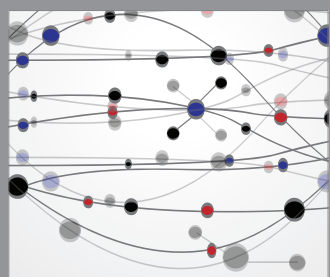

The Scientific World Journal
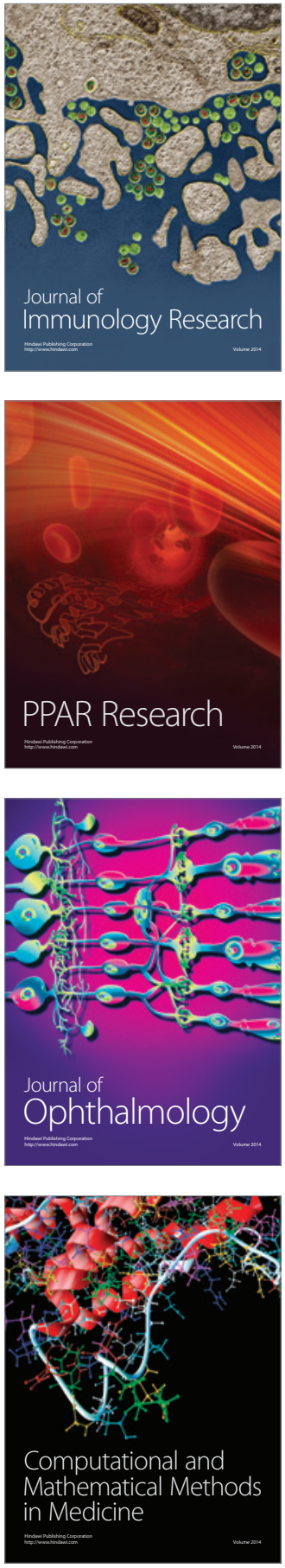

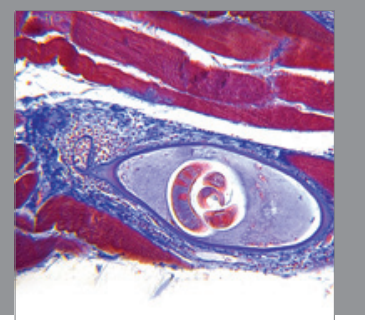

Gastroenterology

Research and Practice
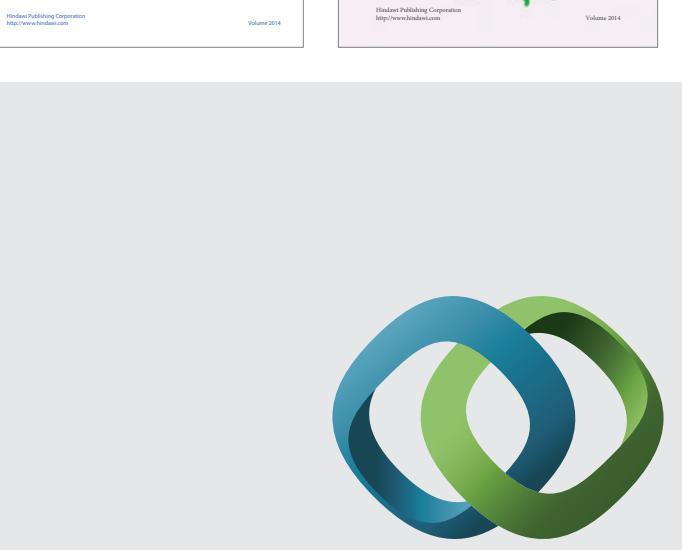

\section{Hindawi}

Submit your manuscripts at

http://www.hindawi.com
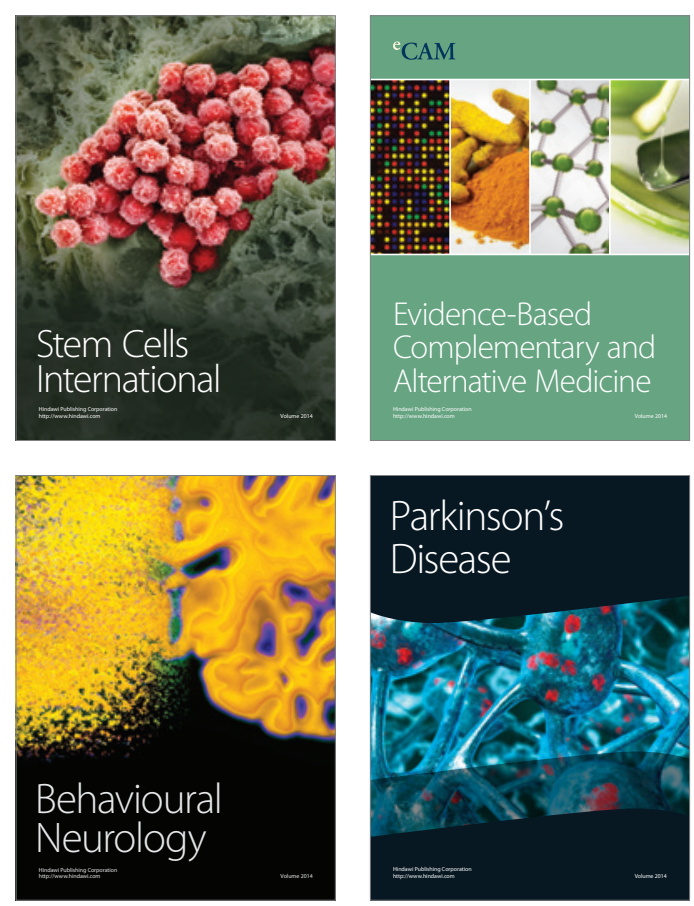

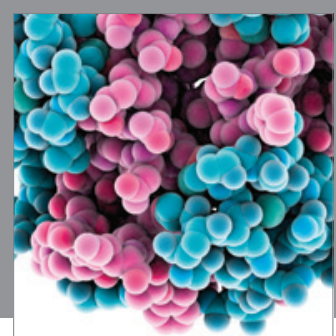

Journal of
Diabetes Research

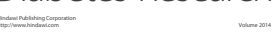

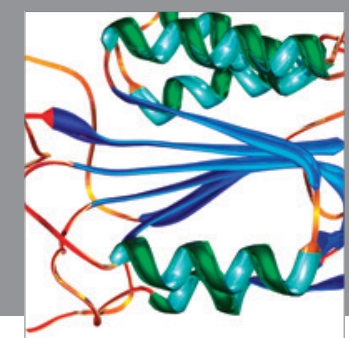

Disease Markers
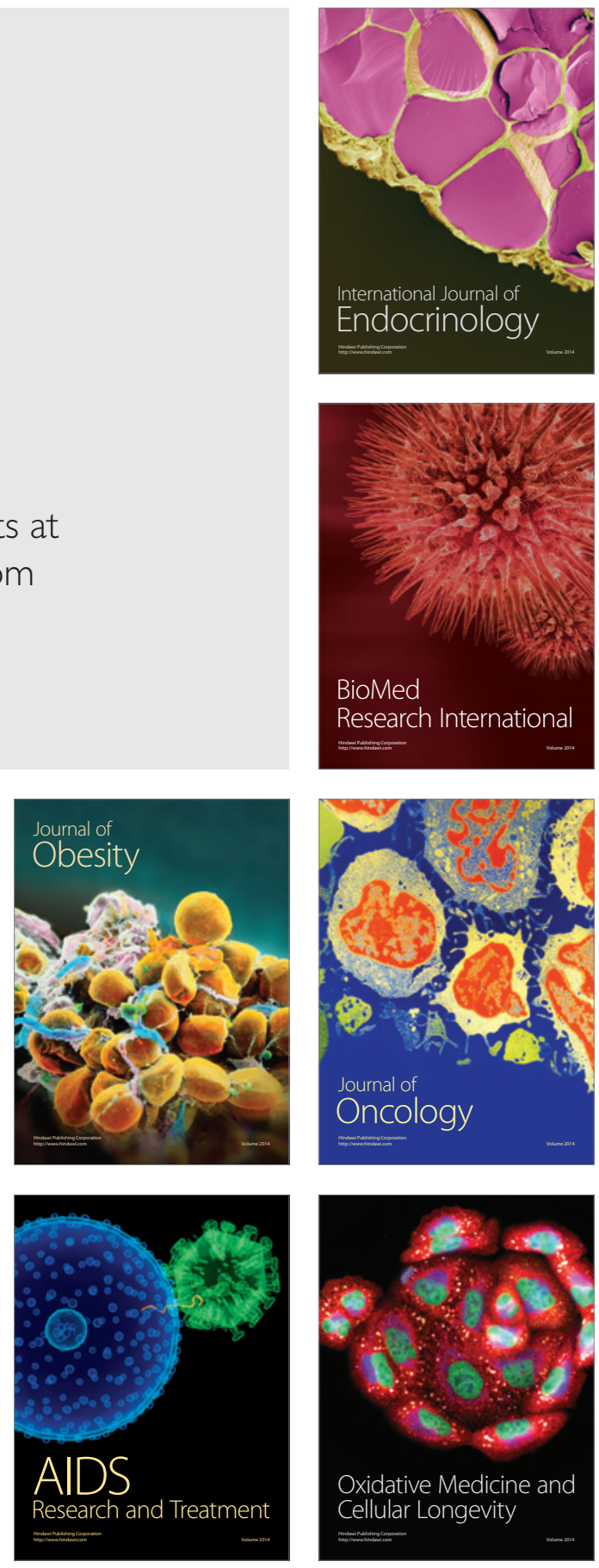